\title{
SYSTEM APPROACH TO AERODROME'S TO PROVISION TO SAFETY FLIGHT
}

\section{СИСТЕМНИЙ ПДХІД ДО АЕРОДРОМНОГО ЗАБЕЗПЕЧЕННЯ БЕЗПЕКИ ПОЛЬОТІВ}

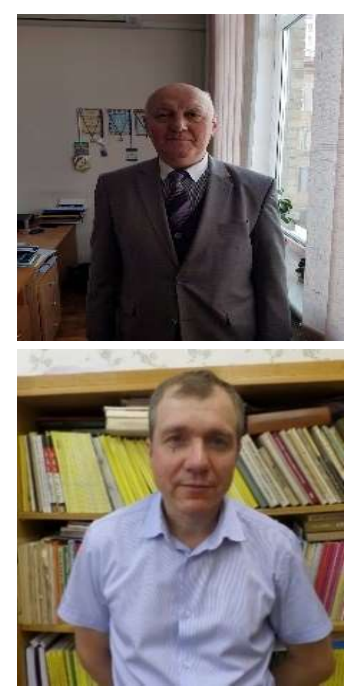

Popelysh Ivan I., Candidate of Engineering Science (Ph.D.), Associate Professor, National Transport University, Associate Professor of the Airports Department, e-mail: i_i_p@ukr.net+38044280-70-73, Ukraine,01010,Kyiv, M. Omelianovycha-Pavlenka Str., 1, office 344, https://orcid.org/0000-0003-1485-2717

Kaskiv Volodymyr I., Candidate of Engineering Science (Ph.D.), Associate Professor, National Transport University, Associate Professor of Department of Transport Construction and Property Management, e-mail:vi_kas@ukr.net,tel.+380504458544, Ukraine, 01010, Kyiv, M. Omelianovycha-Pavlenka Str., 1, office 138,

https://orcid.org/0000-0002-8074-6798

Summary. System approach is considered In article to aerodrome's provide to safety flight. The Designed theorist-plural models given process, allowing develop the methods of the analysis and syntheses of the undertaking the study, methods of their execution and use in theories and practice analysis of the systems operation aerodrome's services civil airport. Example of real exhibit developing models is Shown for onembroidering to safety flight.

The proposed set-theoretical models of the aerodrome flight safety system make it possible to develop a methodology for analyzing and synthesizing research, methods for their implementation, and to apply the theory and practice of the systemology of functioning of aerodrome services of civil airports.

The real application of one of the constituents of the developed models to the use of anti-icing chemicals showed that their effectiveness depends not only on the melting properties, but also on the correct and economical use.

Keywords: safety flight, system approach, management without-danger flight, aerodrome, chemical reagent.

Introduction. Civil aviation at the present stage of development is a complex dynamic system whose main task is to ensure the safety of flights (BP) of aircraft. In general, such a system consists of the following subsystems: "crew — aircraft — air traffic control — flight safety". Each of the subsystems is a corresponding complex system, the components of which can be considered as independent systems and, if necessary, subject them to analysis and synthesis in order to study the quality indicators for improving the organization of safety management.

Main part. One of the components of the "safety assurance" subsystem is aerodrome safety assurance, which includes a set of measures to maintain the aerodrome (runway, taxiway, peron, aircraft parking areas) in their continuous operational readiness and represents a system naturally united into a single whole in accordance with certain principles and related to each other by given relationships.

Aerodrome flight safety is entrusted to the aerodrome service, as the regularity and safe execution of aircraft landing operations depend to a large extent on the preparation of the airfield for flight. 
The solution to the problem of increasing airfield safety at the system level lies in the plane of both formal and informal (qualitative) mathematical methods; the division of large uncertainty (aerodrome flight safety) into simpler components, which are better amenable to research (which corresponds to the notion of analysis), while maintaining a holistic (systemic) understanding of the object of study; development of methods of analysis and synthesis, determining the sequence of stages of the study and methods for their implementation; the need for collective decision-making (by bringing together specialists from different fields of knowledge).

Formally, the aerodrome service is an organization in the form of an airport structural unit responsible for the aerodrome safety of flights. The set-theoretic model M1 of the aerodrome service (AU) is described by the following expression:

$$
\text { M1: ORAS [SP Ap (BP)] } \times \mathrm{TV} \rightarrow \mathrm{AU}[\mathrm{AO}(\mathrm{BP})] \times \mathrm{TV},
$$

where M1 - the model of the aerodrome service in the form of its mapping in the airport structure, the mapping concepts are the sets of this structure;

ORAS - organization (aerodrome service) responsible for BP [1];

SP Ap - the structural unit (SP) of the airport (Ap) (responsible for the provision of airfield BP);

$\mathrm{BP}$ - flight safety;

TV - current time;

$\mathrm{AU}$ - aerodrome service;

AO (BP) - aerodrome flight safety assurance.

Organization of aerodrome safety assurance ORAO (BP) is a system consisting of elements of tangible and intangible origin interconnected by procedural relations in order to ensure the readiness of the aerodrome for safe take-off, landing, taxiing and parking of aircraft. The set-theoretic model M2 of this system is described by the following expression:

$$
\mathrm{M} 2: \mathrm{SiAO}(\mathrm{BP})(\mathrm{EM} \times \mathrm{ENM} \times \mathrm{Pr} \times \mathrm{SC}) \times \mathrm{TV} \rightarrow \text { Or AS }[\mathrm{SP} \text { Ap }(\mathrm{BP})] \times \mathrm{TV}(2)
$$

where M2 - AO (BP) organization model in the form of a display, the concepts of which are sets;

SiAO (BP) - system (airfield support for BP);

EM - elements of material origin;

ENM - elements of intangible origin;

$\mathrm{Pr}-\mathrm{BP}$ processes;

$\mathrm{SC}-$ system goal, $\mathrm{SC} \equiv \mathrm{BP}$, ensuring the readiness of the aerodrome for safe operation as intended.

The system of aerodrome safety assurance of flight of SiAO (BP) is a combination of planned and preventive methods and processes technologically combined with the elements that make up the system in order to prepare the aerodrome for its intended use.

The set-theoretic model M3 of this system is described by the following expression:

$$
\text { M3: } \mathrm{Me}(\mathrm{PP}) \times \mathrm{Pr}(\mathrm{Te}) \times \mathrm{Ob} \times \mathrm{Sb} \times \mathrm{Cp} \times \mathrm{HC} \times \mathrm{Re} \times \mathrm{Ri}(\mathrm{NGo}) \times \mathrm{IP} \times \mathrm{TV} \rightarrow \mathrm{SiAO}(\mathrm{BP})[\mathrm{AO}(\mathrm{BP})] \times \mathrm{TV},
$$

where M3 - model of the system of SiAO (BP) in the form of a mapping, the concepts of which are sets;

$\mathrm{Me}(\mathrm{PP})$ - techniques:

- Me1 (ПП) technique of mechanical cleaning of the surface of airfield coatings from pollutants, snow, ice;

- Method Me2 (ПП) of thermal cleaning of the surface of the surface of airfield coatings from snow and ice formation;

- Me3 (PP) technique for the use of anti-icing chemicals;

- Me4 (PP) methodology for assessing the technical condition of airfield coatings; 
- Me5 (PP) methodology to ensure the readiness of the airfield for take-off and landing operations according to its technical condition;

- Me6 (PP) technique for repairing airfield coatings.

$\mathrm{PP}$ - preventative (methods);

$\operatorname{Pr}(\mathrm{Te})-\mathrm{a}$ technological process (preparation of an airfield for flights);

$\mathrm{Ob}$ - object (airfield);

$\mathrm{Sb}$ - subject (performers);

$\mathrm{Cp}$ - external environment (environment, financial, technical, etc.);

$\mathrm{HC}$ - control action (command to complete the preparation of the airfield for flights);

$\mathrm{Re}$ - material and technical and financial resources (what and how much must be spent to prepare the airfield for flights);

Ri (NGo) - the risk of the airport being unprepared for take-off, landing, taxiing and aircraft parking;

IP - procedures for the information support system (information about the weather, finances, equipment, executors, the state of the airfield, etc.).

The technological process of aerodrome safety assurance - sequentially parallel technological actions to maintain aerodrome coatings and the responsibility of the aerodrome service in the necessary and sufficient situation (condition) for the safe take-off, landing, taxiing and parking of aircraft.

The set-theoretic model M4 of a technological process in which concepts are sets is described by the following expression:

$$
\text { M4: De }(\mathrm{Te}) \times \operatorname{Tr} 1(\mathrm{AS}) \times \operatorname{Tr} 2(\mathrm{AS}) \times \operatorname{Tr} 3(\mathrm{AS}) \times \mathrm{Ca}(\mathrm{BP}) \times \mathrm{TV} \rightarrow \operatorname{Pr}(\mathrm{Te}) \times \mathrm{TV},
$$

where M4 - model of the technological process;

De $(\mathrm{Te})$ - technological activities (to ensure BP);

Tr1 (AS) - territory of responsibility of the aerodrome service of the first stage (IWPP, MRD, KRM, GRM, platform, lighting equipment)

$\operatorname{Tr} 2$ (AS) - the territory of responsibility of the aerodrome service of the 2nd stage (GVPP, MS, connecting taxiways, station square);

$\operatorname{Tr} 3$ (AS) - territory of responsibility of the aerodrome service of the 3rd stage (CPB, BPB, intra-airport access roads, including to radio communication facilities, fuel and lubricants);

$\mathrm{Ca}(\mathrm{BP})$ - a situation ensuring flight safety.

The situation of the aerodrome flight safety process is a set of states (consequences) of the elements of the aerodrome flight support system and the environment that are changed by the events (cause) at the same time.

The set-theoretic model M5 of a situation in which concepts are sets is described by the following expression:

M5: Xia $(\mathrm{EM}, \mathrm{T} 1) \times \mathrm{Xia}(\mathrm{ENM}, \mathrm{T} 1) \times \mathrm{Xia}(\mathrm{Cf}, \mathrm{T} 1) \times \mathrm{St}(\mathrm{T} 1) \times \mathrm{T} 1 \times \mathrm{TV} \rightarrow \mathrm{Ca}(\mathrm{BP}) \times \mathrm{T} 1 \times \mathrm{TV},(5)$

where M5 - a model of the situation in the form of a display in which concepts are sets;

Xia (EM, T1) - the state of elements of material origin at time T1;

Xia (ENM, T1) - the state of elements of intangible origin at time T1;

$\mathrm{Xia}(\mathrm{Cf}, \mathrm{T} 1)$ - the state of the external environment, most often weather conditions, at time T1;

St (T1) - an event that occurred as part of the aerodrome service and / or the influence of the environment at time $\mathrm{T} 1$.

Actions to maintain aerodrome coatings and territories of responsibility of the aerodrome service the activities of subjects of the aerodrome service to achieve a number of events (reason) that bring the aero- 
drome coatings, territories of responsibility of the aerodrome service and the environment to the state (consequence) of readiness / unavailability of the aerodrome for operation as intended in any season of the year and at any time of the day.

The set-theoretic model of the M6 action is as follows:

M6: Dia $(\mathrm{AS}, \mathrm{Sb}) \times \mathrm{St}(\mathrm{T} 2, \mathrm{~T} 3) \times \mathrm{Xia}[\operatorname{Tr} 1(\mathrm{AC})] \times \mathrm{Xia}[\operatorname{Tr} 2(\mathrm{AC})] \times \mathrm{Xia}[\operatorname{Tr} 3(\mathrm{AC})] \times \mathrm{Xia}(\mathrm{Wed}$, $\mathrm{T} 2, \mathrm{~T} 3) \times \mathrm{Xia}(\mathrm{Go}, \mathrm{Ngo}, \mathrm{Ae}, \mathrm{EN}) \times \mathrm{T} 2 \times \mathrm{T} 3 \times \mathrm{TV} \rightarrow \mathrm{De}(\mathrm{Te}) \times \mathrm{T} 2 \times \mathrm{T} 3 \times \mathrm{TV},(6)$

where Dia (AS, Sb) - activity of subjects of the airdrome service;

St (T2, T3) - an event that occurred as part of the aerodrome service and / or the influence of the environment at time $\mathrm{T} 2$ and $\mathrm{T} 3$;

$\mathrm{T} 2$ - time point of any season of the year;

$\mathrm{T} 3$ - any time of day;

Go / Ngo - readiness / unreadiness;

Ae - airfield;

$\mathrm{EN}$ - intended use.

An event (cause) of aerodrome flight safety is a phenomenon in time and space, as a result of the beginning and / or end of a sequence of interdependent technological operations, the influence of logical and semantic decisions on controlled influences on subjects and objects of the aerodrome service, the implementation of procedures for information support and implementation work on material and resource and financial support for the functioning of the aerodrome service.

The set-theoretic model M7 of this event has the following form:

$$
\text { M7: TO (Te, T4, T5) } \times \mathrm{HC}(\mathrm{Sb}, \mathrm{Ob}, \mathrm{T} 6) \times \mathrm{IP}(\mathrm{T} 7) \times \mathrm{Re}(\mathrm{T} 8) \times \mathrm{TV} \rightarrow \mathrm{St}(\mathrm{Ti}) \times \mathrm{TV},
$$

where $\mathrm{TO}(\mathrm{Te}, \mathrm{T} 4, \mathrm{~T} 5)$ - technological operations with the beginning at time $\mathrm{T} 4$ and the end at $\mathrm{T} 5$;

T6 - time of receipt of control actions;

T7 - finishing time of the procedure for the information support system;

T8 - the time of receipt of material and technical and financial resources intended for the aerodrome service.

By definition [2], the sequence of technological operations performed by subjects of the aerodrome service at the facilities is nothing more than sequentially parallel processes. Therefore, TO (Te, T4, T5) $\equiv \mathrm{Pr}$ (Te), and Ti are time points on the axis of the real time scale, then M7 (model (7) will take the following form:

$$
\text { M7: } \mathrm{Pr}(\mathrm{Te}) \times \mathrm{Ob} \times \mathrm{Sb} \times \mathrm{HC} \times \mathrm{IP} \times \mathrm{Re} \times \mathrm{TV} \rightarrow \mathrm{St}(\mathrm{Ti}) \times \mathrm{TV}
$$

The state (consequence) of aerodrome flight safety is a sequence of events that are determined by preventive methods, unplanned events determined by changes in the environment, taking into account the risk that the airfield is not ready to perform its functions within a certain time interval on the real-time axis.

The set-theoretical model M8 of this state has the following form:

$$
\text { M8: } \mathrm{Me}(\mathrm{PP}) \times \mathrm{St}(\mathrm{Ti}) \times \mathrm{Cp} \times \mathrm{Ri}(\mathrm{NG}) \times \mathrm{TV} \rightarrow \mathrm{Xia}(\mathrm{Ti}) \times \mathrm{TV},
$$

where the concept of St (Ti) is subject to decomposition according to the model (8). Then, taking into account minor permutations of the concepts of the M8 model, we have:

$$
\text { M9: } \mathrm{Me}(\mathrm{PP}) \times \operatorname{Pr}(\mathrm{Te}) \times \mathrm{Ob} \times \mathrm{Sat} \times \mathrm{Cp} \times \mathrm{UV} \times \mathrm{Re} \times \mathrm{Ri}(\mathrm{NGo}) \times \mathrm{IP} \times \mathrm{TV} \rightarrow \mathrm{Xia}(\mathrm{Ti}) \times \mathrm{TV}
$$


Comparing model (3) and model (9) we see their full adequacy, that is:

$$
\mathrm{M} 10: \mathrm{M} 9 \equiv \mathrm{M} 3 \leftrightarrow \mathrm{Xia}(\mathrm{Ti}) \times \mathrm{TV} \equiv \mathrm{Si}[\mathrm{AO}(\mathrm{BP})] \times \mathrm{TV}
$$

Conclusion. The set-theoretic model of the aerodrome flight safety system (3) is identical to the state model of aerodrome flight support (9) and can be applied equally to the theory and practice of the systemology of functioning of the aerodrome services of civil airports.

As an example of a real application of the above models, we consider the concept of $\mathrm{Me}(\mathrm{PP})$ - methods, models (3) and one of its components - Me3 (PP) - a technique for using anti-icing chemicals [3]. In turn, this methodology depends on many factors (prevention or removal of ice or snow from the airfield cover, type of airfield cover, thickness of ice or snow on the cover, temperature, humidity, environmental wind force, application of a liquid or granular chemical reagent to the coating, type of chemical reagent and its operational efficiency, the availability of appropriate modern technical means and trained personnel, the applied system for preventing the formation of ice, snow, etc.) and it can It can be considered as a system for the use of airfield anti-icing chireagents, which is organically included in the aerodrome flight safety system. The figures below show the consumption of different types of airfield chemical reagents in $\mathrm{g} / \mathrm{m}^{2}$ and the cost of their use in $\mathrm{UAH} / \mathrm{m}^{2}$, for the prevention and removal of ice $1 \mathrm{~mm}$ thick from the airfield coating at different temperatures (from $0{ }^{\circ} \mathrm{C}$ to $-12{ }^{\circ} \mathrm{C}$ ) for single and multiple application. It can be seen from the graphs that with a single application of the reagent to the coating, the consumption in $\mathrm{g} / \mathrm{m}^{2}$ decreases towards formates, but the price in $\mathrm{UAH} / \mathrm{m}^{2}$ increases, which is explained by the high cost (UAH / $\mathrm{kg}$ ) of chemicals of the formate group. A somewhat different situation is observed with repeated application of reagents to the coating. The general pattern of cost reduction in $\mathrm{g} / \mathrm{m} 2$ is observed but only in a more pronounced form, but at the same time the cost of using reagents of the acetate-formate group in $\mathrm{UAH} / \mathrm{m}^{2}$ is sharply reduced. The cost reduction is explained by a sharp decrease in the number of applications on the coating (at times) and the duration of the reagent on the coating, depending on weather conditions, from 3 to 5 days [4].

\section{Conclusions:}

1. The task of increasing the aerodrome safety of takeoff and landing operations is one of the most difficult components in the overall flight safety system, the solution of which lies in the plane of both formal and informal approaches in this direction.

2. The analysis of the safety task based on the developed set-theoretic models allows us to conduct this study on simpler components, while maintaining a holistic (systemic) understanding of the object of study.

3. The proposed set-theoretical models of the aerodrome flight safety system make it possible to develop a methodology for the analysis and synthesis of research, methods for their implementation, and to apply the theory and practice of the systemology of the functioning of aerodrome services of civil airports.

4. The actual application of one of the components of the developed models to the use of anti-icing chemicals showed that their effectiveness depends not only on the melting properties, but also on the correct and economical use.

\section{References}

1. Shishkov A.F., Zaporozhec V.V., Bilyakovich A.N. Aeroport: Teoriya i praktika zimnego soderzhaniya aerodromov. K. : Dnipro, 2006. $196 \mathrm{~s}$.

2. Frejdina E.V. Issledovanie sistem upravleniya: ucheb. posobie / pod red. Yu.V. Guseva // Vysshaya shkola menedzhmenta. M. : Izd. «Omega - L», 2008. 367 s.

3. Belinskij I.A., Zakrevskij A.I., Shinkarchuk N.V. Tehnicheskaya ekspluataciya aerodromov. K. : KMUGA, 1996. $240 \mathrm{~s}$.

4. Orlov V.A. Teoriya i praktika borby s gololedom. M. : Vozdushnyj transport, 2010. $112 \mathrm{~s}$.

5.Anfilatov V.S. Sistemeyy analiz v upralenii. M.: Finansy i statistika., 2002.- 368 s.

6Antonov A.V. Sistemnyy analiz. M.: Vyssh.shk. 2004. - 454 s. 
7. Novosl'tsev V.I. Tereticheskiye osnovy sistemnogo analiza. M.: Mayor. 2006.- 592 s.

8. Myl'nik V.V. Issledovaniye sistem upravleniya. M.: Delovaya knika. - 2003.-353 s.

9. Gorev A.Ye. Osnovy teorii transportnykh sistem. SPb. 2-10.: - $214 \mathrm{~s}$.

Fig. 1 a
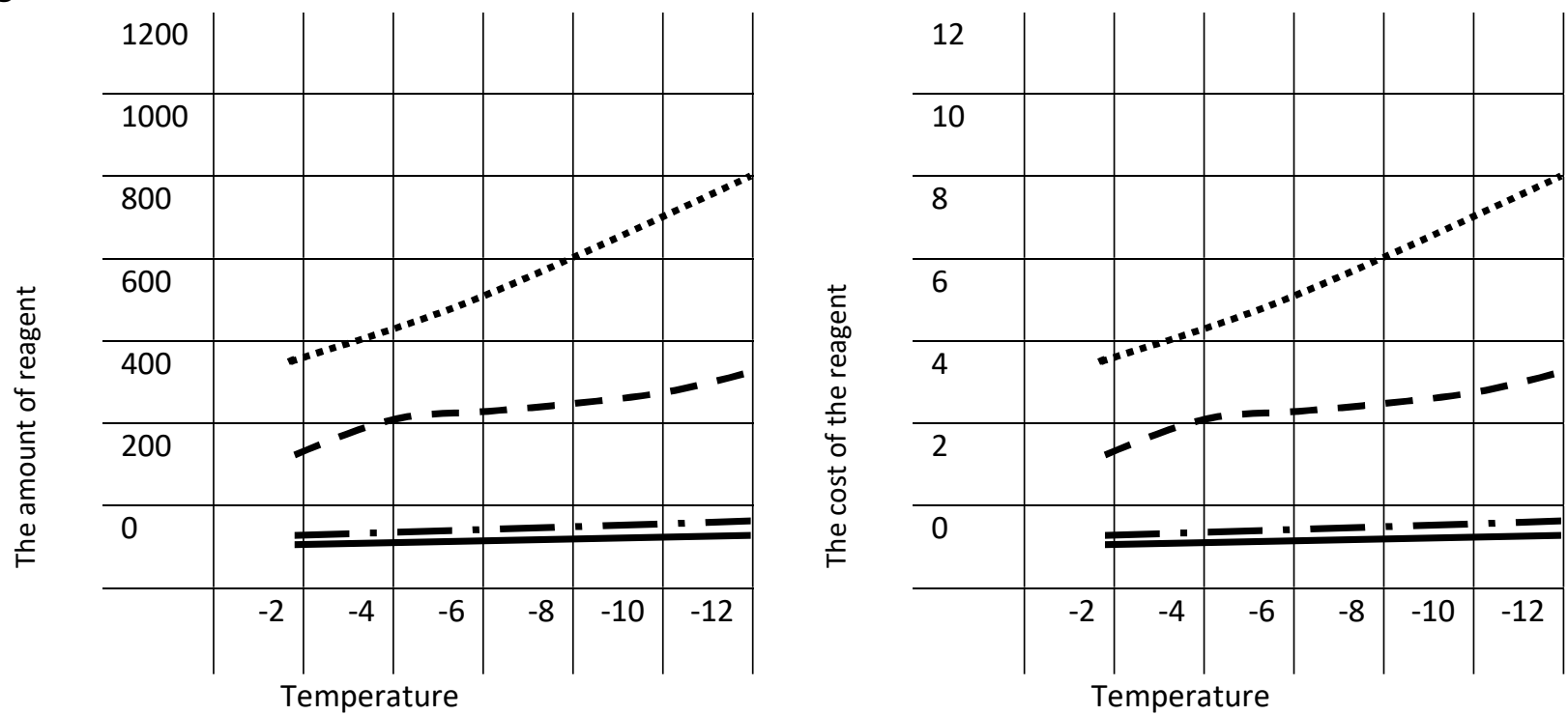

ANS $v$ - ANS $p-$-ANS $v$-ANS $p$

$\cdots$ ANS v - - ANS $p-$ ANS v - ANS $p$

Fig. 1 b
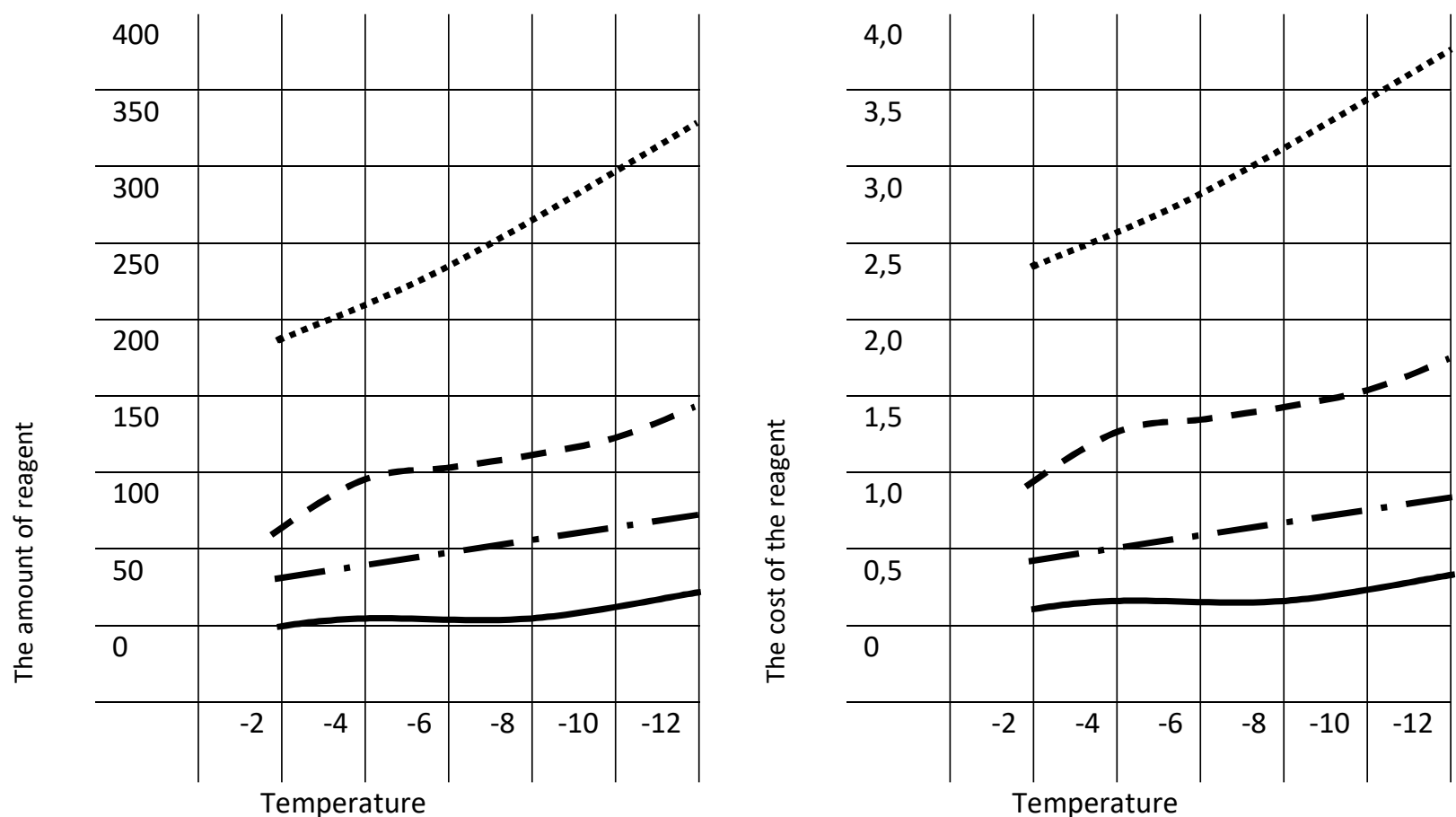

\footnotetext{
.... NKMM v -

NKMM p
}

.... NKMM v - NKMM p - NKMM v

NKMM p 
Fig. $1 \mathrm{c}$

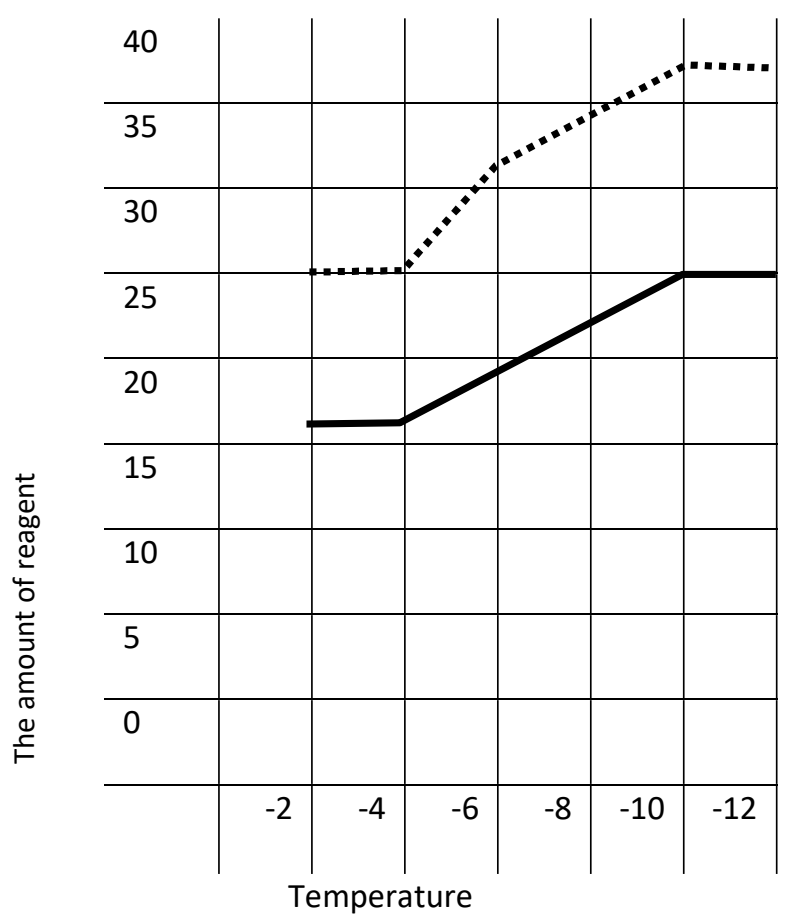

Formate $\mathrm{v} \longrightarrow$ Formate $\mathrm{p}$

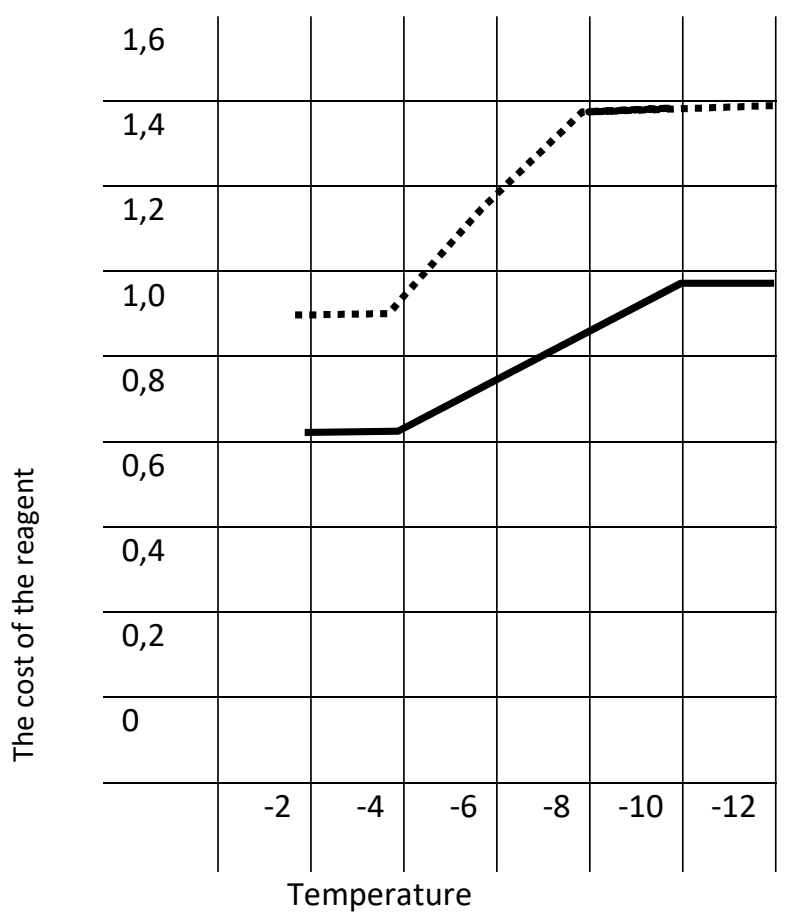

.... Formate $v \quad$ Formate $p$

Figure $1 \mathrm{a}, \mathrm{b}, \mathrm{c}-$ Consumption $\mathrm{g} / \mathrm{m}^{2}$ and the cost of $\mathrm{UAH} / \mathrm{m}^{2}$ of reagents of the urea-nitrate group $(1 \mathrm{a}, \mathrm{b}-\mathrm{ANS}, \mathrm{NKMM}$ ) and formate group (potassium formate $-1 \mathrm{c})$ to remove and prevent ice formation on the runway during disposable (lower part of the drawings) and reusable (upper part of the drawings) their application

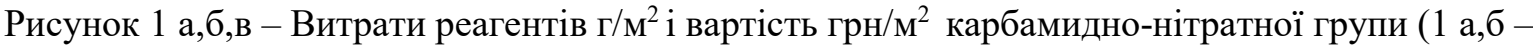
АНC, НКММ) та форміатної групи (форміат калія -1 в) для видалення та попередження льодоснігоутворення на ЗПС при одноразовому (нижня частина рисунків) і багаторазовому (верхня частина рисунків) їх застосуванні

\section{СИСТЕМНИЙ ПІДХІД ДО АЕРОДРОМНОГО ЗАБЕЗПЕЧЕННЯ БЕЗПЕКИ ПОЛЬОТІВ}

Попелиш Іван Іванович, кандидат технічних наук, доцент, Національний транспортний університет, доцент кафедри аеропортів, e-mail: i_i_p@ukr.net, тел. + 38044280-70-73, Україна, 01010, м. Київ, вул. М. Омеляновича-Павленка, 1, к. 344. https://orcid.org/0000-0003-1485-2717

Каськів Володимир Іванович, кандидат технічних наук, доцент, Національний транспортний університет, доцент кафедри транспортного будівництва та управління майном e-mail: vi_kas@ukr.net, тел. +380504458544, Україна, 01010, м. Київ, вул. М. Омеляновича-Павленка, 1, к. 138.

https://orcid.org/0000-0002-8074-6798

Анотація. Цивільна авіація на сучасному етапі розвитку являє собою складну динамічну систему, головним завданням якої є забезпечення безпеки польотів (БП) повітряних суден. У загальному вигляді така система складається з наступних підсистем: «екіпаж - повітряне судно - управління повітряним рухом - убезпечення польотів». Кожна 3 підсистем може представляти із себе відповідну складну систему, складові частини якої можна розглядати як самостійні системи і при необхідності 
піддавати їх аналізу і синтезу з метою вивчення індикаторів якості по поліпшенню організації управління безпекою польотів. Однієї зі складової підсистеми «убезпечення польотів» є аеродромне убезпечення польотів, яке включає комплекс заходів щодо підтримання аеродрому (ЗПС, РД, перонів та місць стоянок повітряних суден) у їх постійній експлуатаційній готовності і представляє систему, частини якої можна розглядати як іiї складові, закономірно об'єднані в єдине ціле відповідно до певних принципів і пов'язаних між собою заданими відносинами.

Аеродромне убезпечення польотів покладене на аеродромну службу, так як регулярність і безпека злітно-посадкових операцій повітряних суден у значній мірі залежить від підготовки льотного поля до польотів.

Рішення задачи підвищення аеродромного убезпечення польотів на системному рівні лежить у площині як формальних, так і неформальних (якісних) математичних методів, розчленовування великої невизначеності (аеродромна безпека польотів) на більш прості складові, які краще піддаються дослідженню (що і відповідає поняттю аналіз), при збереженні цілісного (системного) підходу до об'єкту дослідження; розробки методики аналізу і синтезу, що обумовлює послідовність етапів проведення дослідження і методи їх виконання; необхідності колективного ухвалення рішення (об'єднанням фахівців різних галузей знань).

У статті розглянутий системний підхід до аеродромного забезпечення польотів. Розроблені теоретико-множинні моделі даного процесу, які дозволяють розробляти методику аналізу і синтезу проведення дослідження, методи їх виконання і застосовувати в теорії і практиці системології функціонування аеродромних служб цивільних аеропортів. Наведений приклад реального застосування розроблених моделей для підвищення безпеки польотів.

Запропоновані теоретико-множинні моделі системи аеродромного забезпечення безпеки польотів дозволяють розробляти методику аналізу та синтезу проведення дослідження, методи їх виконання, і застосовувати в теорії і практиці системології функціонування аеродромних служб цивільних аеропортів. Реальне впровадження однієї із складових розроблених моделей до застосування протиожеледних хімічних реагентів показало, що їх ефективність залежить не тільки від плавильних властивостей, але і від правильного й економного застосування.

Ключові слова: безпека польотів, системний підхід, управління безпекою польотів, аеродром, хімреагенти.

\section{Перелік посилань}

1. Шишков А.Ф., Запорожец В.В., Билякович А.Н. Аэропорт: Теория и практика зимнего содержания аэродромов. К. : Дніпро, 2006. 196 с.

2. Фрейдина Е.В. Исследование систем управления: учеб. пособие / под ред. Ю.В. Гусева // Высшая школа менеджмента. М. : Изд. «Омега - Л», 2008. 367 с.

3. Белинский И.А., Закревский А.И., Шинкарчук Н.В. Техническая эксплуатация аэродромов. К. : КМУГА, 1996. 240 c.

4. Орлов В.А. Теория и практика борьбы с гололедом. М. : Воздушный транспорт, 2010. 112 с.

5.Анфилатов В.С. Системеый анализ в упралении. М.: Финансы и статистика., 2002.- 368 с.

6.Антонов А.В. Системный анализ. М.: Высш.шк. 2004. - 454 с.

7. Новосльцев В.И. Теретические основы системного анализа. М.: Майор. 2006.- 592 с.

8. Мыльник В.В. Исследование систем управления. М.: Деловая кника. $-2003 .-353$ с.

9. Горев А.Е. Основы теории транспортных систем. СПб. 2-10.: - 214 с. 